\title{
ECONOMICA
}

Journal of Economic and Economic Education Vol.3 No.1 (18-26)

\section{ANALISIS EFEKTIFITAS PROGRAMPELATIHAN DIKLAT PIM III TERHADAP KOMPETENSI PEJABAT ESELON III DI PEMERINTAH KABUPATEN AGAM}

\author{
Dina Amaluis \\ Dosen Program Studi Pendidikan Ekonomi STKIP- PGRI Sumbar \\ Jl. Gunung Pangilun No.1, Padang Sumatera Barat \\ Email :dina.amaluis@gmail.com \\ submited: 2014.05.16 reviewed:14.07.30 accepted: 2014.10.30 \\ http://dx.doi.org/10.22202/economica.2014.v3.i1.232
}

\begin{abstract}
In the management of Human Resources, there are several basic functions. The evaluation function is one of them, in addition to planning, organizing and execution. Training programs as one strategy of human resource development requires the evaluation function to determine the effectiveness of ProgramPelatihan.Program Training for Civil Servants aims to improve the ability to lead, work competence and performance. In this study, the training program is intended Leadership Training Level III. This study aims to measure the relationship to increased Competence Training Program. Respondents consisted of 96 graduates of Leadership Training Level III who currently holds the post of structural Echelon III in Agam district government (leader). The approach used is quantitative by distributing a questionnaire to all respondents. Training Program evaluation method using Kirkpatrick \& Kirkpatrick. The analysis used is a simple correlation between variables see significant value. The result showed that the training program is significantly correlated to the increased competence. This means that any increase in the value of the variable training program will be followed by a rise in the value of the variable competence. From this research can be concluded that the organizers of the training program is necessary to conduct in-depth Training Needs Analysis
\end{abstract}

\begin{abstract}
Abstrak
Dalam manajemen Sumber Daya Manusia terdapat beberapa fungsi pokok. Fungsi evaluasi merupakan salah satu diantaranya, selain perencanaan, pengorganisasian dan pelaksanaan. Program Pelatihan sebagai salah strategi pengembangan Sumber Daya Manusia memerlukan fungsi evaluasi untuk mengetahui efektivitas ProgramPelatihan.Program Pelatihan bagi Pegawai Negeri Sipil bertujuan untuk meningkatkan kemampuan memimpin, kompetensi kerja dan kinerja. Dalam penelitian ini, program pelatihan yang dimaksud ialah Diklat Kepemimpinan Tingkat III. Penelitian ini bertujuan untuk mengukur hubungan Program Pelatihan terhadap peningkatan Kompetensi. Responden terdiri dari 96 orang lulusan Diklat Kepemimpinan Tingkat III yang saat ini memegang jabatan stuktural Eselon III pada Pemerintah Kabupaten Agam (leader). Pendekatan yang digunakan ialah kuantitatif dengan menyebarkan kuesioner ke semua responden. Metode evaluasi Program Pelatihan menggunakan metode Kirkpatrick \& Kirkpatrick. Analisa yang digunakan ialah korelasi sederhana dengan melihat nilai signifikasi antar variabel. Berdasarkan hasil penelitian diperoleh bahwa Program Pelatihan berkorelasi signifikan terhadap peningkatan Kompetensi. Artinya setiap kenaikan nilai variabel Program Pelatihan akan diikuti dengan kenaikan nilai variabel Kompetensi. Dari penelitian ini dapat disimpulan bahwa penyelenggara program pelatihan dipandang perlu untuk melakukan Analisa Kebutuhan Pelatihan secara mendalam.
\end{abstract}

Keywords : Training programs, public sector, Competence

C2014 Prodi Pendidikan Ekonomi STKIP PGRI, Padang 


\section{PENDAHULUAN}

Organisasi memerlukan sumber daya manusia yang memiliki kompetensi. Konsep pengembangan sumber daya manusia berbasis kompetensi merupakan salah satu langkah yang dilakukan agar dapat memberikan hasil yang sesuai dengan tujuan dan sasaran organisasi. Metode pelatihan (training) merupakan salah satu metode yang paling banyak ditempuh. Alasannya, metode pelatihan dapat meningkatkan nilai tambah karyawan(employee value).

Pemerintah Daerah sebagai sebuah organisasi sektor publik melalui UndangUndang Nomor 32 Tahun 2004 tentang Pemerintahan Daerah memandang upaya peningkatan sumber daya aparatur sebagai modal dasar (human capital) yang sangat strategis dan memiliki nilai tinggi.Pasal 133 Undang-Undang Nomor 32 Tahun 2004 menjelaskan bahwa pengembangan karir Pegawai Negeri Sipil Daerah mempertimbangkan integritas dan moralitas, pendidikan dan pelatihan, pangkat, mutasi jabatan, mutasi antar daerah, dan kompetensi.

Untuk memayungi konsep tersebut, sebelumnya Pemerintah telah menetapkan Undang-Undang Nomor 43 tahun 1999 tentang Pokok-Pokok Kepegawaian, dimana ditetapkan visi pengembangan sumber daya manusia aparatur yaitu mewujudkan SDM aparatur yang profesional, netral dan sejahtera. Berdasarkan visi tersebut, diciptakan misi: menyelenggarakan manajemen Pegawai Negeri Sipil yang mencakup perencanaan, pengembangan kualitas dan administrasi kepegawaian, pengawasan dan pengendalian, penyelenggaraan dan pemeliharaan, informasi kepegawaian, mendukung perumusan kebijakan kesejahteraan pegawai, serta memberikan bimbingan teknis kepada instansi Pemerintah dan Pemerintah Daerah.

Untuk dapat membentuk sosok PNS yang sesuai dengan visi misi di atas, perlu dilaksanakan pembinaan melalui jalur Pendidikan dan Pelatihan (Diklat) bagi seluruh PNS. Terutama terhadap PNS dalam jabatan struktural karena berperan sebagai pengelola dan pelaksana kebijakan publik. Pelatihan dan pengembangan yang pernah diadakan yaitu pada tahun 2009 sebanyak 9 orang PNS Kabupaten Agam dikirim untuk mengikuti Diklatpim III, pada tahun 2010 sebanyak 8 orang, dan pada tahun 2011 sebanyak 8 orang. Adapun pelaksanaannya diadakan di Pusat Diklat Depdagri Agam atau Balai Diklat Provinsi Sumatera Barat.

Berdasarkan Peraturan Pemerintah Nomor 101 Tahun 2000 tentang Pendidikan dan Pelatihan Pegawai Negeri Sipil diamanatkan bahwa sasaran pendidikan dan pelatihan (diklat) adalah mewujudkan Pegawai Negeri Sipil (PNS) yang memiliki kompetensi sesuai dengan persyaratan jabatan masing-masing. Berbagai diklat bagi PNS kemudian diselenggarakan untuk dapat memenuhi tuntutan kebutuhan kompetensi jabatan-jabatan tersebut.

Adapun pada langkah awal dalam proses pengembangan kompetensi PNS ini adalah melalui penyelenggaraan diklat prajabatan, yaitu diklat untuk membentuk 
wawasan kebangsaan, kepribadian dan etika Calon Pegawai Negeri Sipil (CPNS) serta memberikan pengetahuan dasar tentang sistem penyelenggaraan Pemerintahan Negara dan tentang bidang tugas serta budaya organisasinya agar mampu melaksanakan tugas jabatan sebagai Pegawai Negeri Sipil.

Kemudian jika seorang PNS akan atau telah menduduki suatu jabatan struktural, maka bagi PNS tersebut harus telah mengikuti Diklat Kepemimpinan untuk level eselon jabatan tersebut. Hal ini bertujuan untuk meningkatkan pengetahuan, keterampilan, sikap dan perilaku PNS agar sesuai dengan kompetensi yang dibutuhkan dalam jabatan mereka.

Sejalan dengan hal diatas, untuk mewujudkan pemerintahan yang baik, diperlukan sumber daya manusia aparatur yang memiliki kompetensi jabatan dalam penyelenggaraan Negara dan Pembangunan. Ini terjadi karena sifat pekerjaan dan organisasi modern mulai berubah. Seperti dikemukakan oleh Stroud(2009) bahwa saat ini semua bentuk organisasi telah dihadapkan pada banyaknya kemajuan dibidang komunikasi dan informasi sehingga telah mempersingkat rencana dan pengambilan keputusan yang pada akhirnya tercipta kompetisi antara organisasi dengan organisasi lainnya.

Salah satu program diklat yang dikembangkan bagi peningkatan kompetensi pemangku jabatan struktural adalah program diklat kepemimpinan (Diklatpim). Sebagaimana dinyatakan dalam PP Nomor
101 tahun 2000 Pasal 10, program ini dimaksudkan untuk meningkatkan kompetensi kepemimpinan para pejabat struktural calon pemangku atau yang telah memangku jabatan struktural baik di pusat maupun daerah. yaitu disebut dengan Diklat Kepemimpinan, yang terdiri dari: Diklatpim Tingkat IV adalah Diklatpim untuk jabatan Struktural Eselon IV, Diklatpim Tk. III adalah Diklatpim untuk jabatan Eselon III, Diklatpim Tk. II adalah Diklatpim untuk jabatan Eselon II dan Diklatpim Tk. I adalah Diklatpim untuk jabatan Eselon I.

Hubungan diklat terhadap kompetensi menjadi salah satu dasar dalam penetapan Keputusan Kepala LAN RI Nomor 540/XIII/10/6/2001. Dimana unsur kompetensi adalah kemampuan dan karakteristik yang dimiliki oleh seorang PNS. Sejalan dengan itu, dalam Peraturan Pemerintah Nomor 101 tahun 2000, Diklatpim memiliki sasaran mewujudkan PNS yang memiliki kompetensi teknis, dan manajerial.

Hooper and Holmes (2000) menyebutkan bahwa core competence dapat dibentuk dengan teaching, training or learning. Hoofman (1999;275) bahkan menyebutkan terdapat hubungan diklat terhadap kompetensi sekaligus kinerja yaitu "the term "competency" has not been clearly defined in the literature. Two main meanings of the term have been identified, one referring to the outputs, or results of training that is, competent performance". Sependapat dengan hal itu, Al-Ajlouni et al (2010) menyebutkan bahwa pelatihan 
bertujuan untuk meningkatkan kemampuan dan pengetahuan karyawan untuk melaksanakan pekerjaan. Dalam sumber yang sama, William G. Torpey menyebutkan training as "the process of developing skills, habits, knowledge and attitudes in employees for the purpose of increasing effectiveness of employees in their present government positions as well as preparing employees for future government positions".

\section{Penelitian Sebelumnya}

Hubungan diklat terhadap kompetensi menjadi salah satu dasar dalam penetapan Keputusan Kepala LAN RI Nomor 540/XIII/10/6/2001. Dimana unsur kompetensi adalah kemampuan dan karakteristik yang dimiliki oleh seorang PNS. Sejalan dengan itu, dalam Peraturan Pemerintah Nomor 101 tahun 2000, Diklatpim memiliki sasaran mewujudkan PNS yang memiliki kompetensi teknis, dan manajerial.

Hooper and Holmes menyebutkan bahwa core competence dapat dibentuk dengan teaching, training or learning. Hoofman (1999;275) bahkan menyebutkan terdapat hubungan diklat terhadap kompetensi sekaligus kinerja yaitu "the term "competency" has not been clearly defined in the literature. Two main meanings of the term have been identified, one referring to the outputs, or results of training that is, competent performance". Sependapat dengan hal itu, Al-Ajlouni et al (2010) menyebutkan bahwa pelatihan bertujuan untuk meningkatkan kemampuan dan pengetahuan karyawan untuk melaksanakan pekerjaan. Dalam sumber yang sama, William G. Torpey menyebutkan training as "the process of developing skills, habits, knowledge and attitudes in employees for the purpose of increasing effectiveness of employees in their present government positions as well as preparing employees for future government positions".

Lukito (2004) dalam penelitiannya Analisis Efektifitas Program Pengembangan Karyawan Melalui Pendidikan Dan Pelatihan di RS. DR. M. Djamil Padang. Subjek penelitiannya terdiri dari 180 orang staf rumah sakit yang telah dididik dan dilatih. Metode yang digunakan ialah metode Kirkpatrick. Salah satu kesimpulan yang diperoleh dalam penelitian ini bahwa tujuan dari pelaksanaan pendidikan dan pelatihan bagi karyawan adalah untuk meningkatkan skill, knowledge dan ability karyawan sehingga mampu meningkatkan kompetensi pelayanan.

\section{Permasalahan}

Berdasarkan uraian diatas, maka penulis merumuskan permasalahan sebagai berikut :

"Bagaimana Hubunganefektifitas

programpelatihan DIKLAT PIM III terhadap kompetensi pejabat eselon III di Pemerintah Kabupaten Agam? “

\section{Hipotesis}

Tujuan dari penelitian ini ialah untuk mengetahui keterkaitan antara efektivitas program pelatihan DIKLATPIM III terhadap kompetensi pejabat eselon III. Objek penelitiannya adalah gabungan peserta 
Diklatpim III dengan peserta Diklatpim IV pada Pusdiklat BPS 2009. Dari hal ini diambil hipotesis:

$\begin{array}{cc}H_{a}: \quad \text { Program } & \text { Pelatihan } \\ \text { BerkorelasiSignifikan } & \text { Terhadap } \\ \text { Peningkatan Kompetensi } & \end{array}$

\section{METODE PENELITIAN}

\section{Populasi dan Sampel}

Populasi dalam penelitian ini dibagi menjadi dua kategori sesuai dengan objek dan tujuan penelitian, yaitu:

a. Populasi pertama adalah seluruh PNS yang telah mengikuti dan lulus program pelatihan kepemimpinan tingkat III. Data terakhir yang diperoleh dari Bidang Diklat BKD, terdapat 96 orang PNS yang telah mengikuti dan lulus program pelatihan tersebut. Dengan kata lain, teknik pengambilan sampel menggunakan metode sensus, yaitu seluruh populasi merupakan sampel. Kepada sampel diberikan kuesioner pengukuran efektifitas pelatihan. Populasi kedua adalah seluruh PNS yang didalam struktur organisasi berada dibawah garis komando (follower) PNS pada populasi pertama pada masing-masing SKPD. Metode pengambilan sampel menggunakan metode purposive sampling, yaitu satuan sampling dipilih berdasarkan pertimbangan tertentu dengan tujuan untuk memperoleh satuan sampling yang memiliki karakteristik yang dikehendaki (Singarimbun dan
Effendi;1989). Peneliti mengambil keputusan untuk memberikan kuesioer kepada tiap satu orang PNS pada jabatan eselon IV/a yang merupakan bawahan (substitute) dari sampel sebagaimana dimaksud pada huruf a diatas. Sehingga jumlah sampel pada kategori ini sebanyak 96 orang pejabat eselon IV/a.

\section{Data dan Sumber Data}

a) Pengumpulan data primer dilakukan dengan cara menyebarkan kuesioner kepada responden. Kuesioner Efektivitas Program pelatihan. Sedangkan kuesioner kepemimpinan diberikan kepada bawahan dari pejabat struktural eselon III.

b) Pengumpulan data sekunder dilakukan dengan mengumpulkan data-data di Badan Kepegawaian Daerah dan Bagian Organisasi Sekretariat Daerah.

c) Studi dokumentasi/pengumpulan data dalam bentuk dokumen tertulis. Data yang dimaksud bisa merupakan undangundang, peraturan, hasil studi/riset, pernyataan, teori yang relevan, serta bahan lainnya yang berkaitan dengan masalah yang diteliti.

d) Browsing dan clipping print, yaitu pencarian bahan-bahan yang relevan dengan masalah yang diteliti melalui media internet.

Variabel Penelitian
A. Variabel Efektifitas Program Pelatihan
a. Dimensi Evaluasi Reaksi, dengan indikator :


- Reaksi terhadap pelaksanaan diklat;

- Reaksi penggunaan media;

- Reaksi penyajian materi;

- Reaksi manfaat;

- Reaksi penyampaian materi;

- Reaksi program;

- Reaksi pelayanan makanan;

- Reaksi fasilitas asrama;

- Reaksi penyelenggaraan diklat;

- Reaksi materi yang disampaiakan;

- Reaksi kualitas dan kemampuan pengajar;

- Reaksi kesigapan penyelenggaraan diklat;

b. Dimensi Evaluasi Pembelajaran, dengan indikator :

- Kemampuan mengidentifikasi masalah;

- Kemampuan menganalisis masalah;

- Kemampuan memecahkan masalah;

- Kemampuan sistematika penulisan;

- Kemampuan presentasi;

- Kemampuan penguasaan materi;

- Kesungguhan berpartisipasi;

- Kualitas hasil pemikiran;

- Keefektifan dalam penyampaian pertanyaan, jawaban \& tanggapan;

- Kemampuan dalam mengidentifikasi masalah;

- Kemampuan menempatkan diri;

- Kualitas pemikiran;

- Kemampuan teknik menyampaikan pertanyaan;

- Kemampuan mengakomodasi;

c. Dimensi Evaluasi Perilaku, dengan indikator :

- Kerapihan berpakaian;

- Ketepatan hadir;

- Kesungguhan mengikuti kegiatan;

- Kejujuran \&kesanggupan dalam melaksanakan tugas;

- Konsistensi \& tanggungjawab

- Visioner;
- Pemberdayaan;

- Demokratis;

- Kontribusi dalam penyelesaian tugas bersama;

- Membina keutuhan \& kekompakan kelompok;

- Tidak mendominasi kelompok;

- Mau menerima pendapat orang lain;

- Membantu membuat iklim diklat bergairah;

- Mampu membuat saran demi kelancaran diklat;

- Aktif mengajukan pertanyaan yang relevan;

- Mampu mengendalikan diri, waktu, situasi \& lingkungan;

d. Dimensi Evaluasi Hasil, dengan indikator :

- Inisiatif \& prakarsa yang mendukung produktifitas organisasi;

- Melaksanakan pekerjaan \& hal-hal baru;

- Kebebasan kepada karyawan untuk mendiskusikan berbagai masalah dengan pemimpinnya;

- Memberikan kebebasan dalam melaksanakan pekerjaan tanpa diawasi;

- Pekerjaan yang baik \& unggul akan mendapat penghargaan;

- Kesetiakawanan dalam satuan kerja;

- Pola komunikasi yg positif antara atasan \& bawahan;

- Hasil pekerjaan senantiasa tercapai sesuai kualitas;

- Kualitas pekerjaan sesuai dengan yang diinginkan;

- Kesalahan jarang terjadi;

- Beban organisasi \& dicapai;

- Beban organisasi dapat dicapai tanpa pemborosan;

- Pujian \& penghargaan dilakukan pimpinan kepada pegawai yang berpretasi; 
- Karyawan senang meningkatkan hasil kerja;

- Karyawan suka memperbaiki hasil kerjanya;

- Karyawan senang meningkatkan hasil kerja;

- Karyawan suka memperbaiki hasil kerjanya;

- Karyawan senang menyelesaikan hasil kerjanya lebih cepat;

- Karyawan masuk kantor tepat waktu;

- Pada waktu jam kerja, karyawan memanfaatkan waktu untuk belajar;

- Pada waktu jam istirahat, karyawan suka mengerjakan pekerjaannya;

B. Variabel Kompetensi

a. Dimensi Keterampilan (skills), dengan indikator :

- Kecepatan penggunaan sumberdaya;

- Ketepatan penggunaan sumberdaya;

- Peningkatan produktivitas;

- Kemampuan memenuhi standar kualitas;

- Kemampuan mengembangkan keterampilan;

- Kemampuan menularkan keterampilan;

b. Dimensi Sikap, dengan indikator :

- Sikap terhadap tugas utama;

- Sikap terhadap waktu kerja;

- Sikap terhadap kerjasama tim;

- Keinginan pindah tugas;

- Etos kerja;

- Sikap tanggap;

- Kepercayaan diri;

- Sikap terhadap imbalan;

- Sikap terhadap kritik;

c. Dimensi Perilaku (Behavior), dengan indikator :

- Kreativitas;

- Disiplin;

- Kepedulian;

- Opportunistis;

- Kemandirian;
- Orientasi masa depan;

d. Dimensi Pengetahuan (Knowledge), dengan indikator :

- Meningkatnya pengetahuan;

- Pengetahuan manajerial;

- Pengetahuan operasional;

- Knowledge sharing;

- Pengetahuan akan resiko;

- Pengetahuan misi;

- Pengetahuan perumusan masalah; Pengukuran Variabel

Untuk penilaian dilakukan dengan sensus skala Likert, dimana tiap pertanyaan diberi skor jawaban 1,2,3,4, dan 5, skor tertinggi tiap jawaban adalah 5 (lima) dan skor terendah adalah 1 (satu). Skala Likert digunakan untuk mengukur sikap, pendapat, dan persepsi seseorang atau sekelompok tentang kejadian atau gejala sosial. Dalam penelitian gejala sosial ini telah ditetapkan secara spesifik oleh peneliti, yang selanjutnya disebut sebagai variabel penelitian (Riduwan, 2007:12)

Dengan skala Likert, maka variabel yang akan diukur dijabarkan dimensi, dimensi dijabarkan menjadi sub-variabel kemudian sub-variabel dijabarkan menjadi indikator variabel yang dapat diukur. Kemudian indikator tersebut dijadikan sebagai titik tolak untuk menyusun itemitem instrumen yang dapat berupa pernyataan atau pertanyaan.

Metode dan Pengujian Hipotesis

Uji Normalitas

Uji normalitas digunakan untuk mengetahui apakah populasi data 
berdistribusi normal atau tidak. Uji ini biasanya digunakan untuk mengukur data berskala ordinal, interval, ataupun rasio. Jika analisis menggunakan metode parametrik, maka persyaratan normalitas harus terpenuhi yaitu data berasal dari distribusi yang normal. Jika data tidak berdistribusi normal, atau jumlah sampel sedikit dan jenis data adalah nominal atau ordinal maka metode yang digunakan adalah statistik non parametrik. Dalam pembahasan ini akan digunakan uji One Sample KolmogorovSmirnov dengan menggunakan taraf signifikansi 0,05. Data dinyatakan berdistribusi normal jika signifikansi lebih besar dari 5\% atau 0,05 (Prayitno: 2012).

\section{UjiKorelasi}

Untuk menguji keeratan atau kadar hubungan antar variabel sebagai pembuktian hipotesis yang telah ditetapkan, digunakan uji korelasimenggunakan persamaan sebagai berikut:

$$
r_{x y}=\frac{n \sum X Y-\left(\sum X\right)\left(\sum Y\right)}{\sqrt{\left\{n \sum X^{2}-\left(\sum X\right)^{2}\right\}\left\{n \sum Y^{2}-\left(\sum Y\right)^{2}\right\}}}
$$

dimana :

$$
\begin{aligned}
& \mathrm{n}=\text { Banyaknya Pasangan data X } \\
& \text { dan Y } \\
& \Sigma \mathrm{x} \quad=\text { Total Jumlah dari Variabel X } \\
& \Sigma \mathrm{y} \quad=\text { Total Jumlah dari Variabel Y } \\
& \Sigma \mathrm{x}^{2}=\text { Kuadrat dari Total Jumlah } \\
& \text { Variabel X } \\
& \Sigma \mathrm{y}^{2}=\text { Kuadrat dari Total Jumlah } \\
& \text { Variabel Y } \\
& \Sigma x y=\text { Hasil Perkalian dari Total } \\
& \text { Jumlah Variabel X dan Variabel Y }
\end{aligned}
$$

Analisis korelasi digunakan untuk mengetahui derajat (tingkat keeratan) hubungan linear antar dua buah variabel atau lebih. Variabel ini terdiri dari variabel bebas dan tergantung. Ukuran yang digunakan untuk mengetahui derajat hubungan antar variabel disebut koefisien korelasi. Besarnya hubungan berkisar antara 0 sampai dengan 1 . Jika mendekati angka 1 berarti hubungan kedua variabel semakin kuat, demikian juga sebaliknya jika mendekati angka 0 berarti hubungan kedua variabel semakin lemah.

Korelasi antara variabel terikat dengan variabel terikat dapat menghasilkan angka positif (+) dan negatif (-). Variabel tersebut bisa berhubungan dengan salah satu dari 3 cara berikut:

a) Hubungan Positif. Artinya nilai $r=+1$ menunjukan bahwa kedua peubah memiliki kecenderungan yang sama, yaitu kenaikan nilai $X$, diikuti dengan kenaikan nilai $Y$, demikian juga sebaliknya penurunan nilai $X$ diikuti dengan penurunan nilai $Y$ hubungan bersifat searah. Searah artinya jika variabel bebas besar, variabel terikat semakin besar.

b) Tidak Ada Hubungan. Artinya, Nilai $r=$ 0 menunjukan bahwa kedua peubah tidak berkorelasi, yaitu kenaikan atau penurunan nilai peubah $\mathrm{X}$, tidak mempengaruhi nilai peubah $Y$. Pengaruh variabel bebas akan tetap sama kendati terdapat variabel terikat.

c) Hubungan Negatif. Artinya, hubungan bersifat tidak searah. Korelasi negatif 
menunjukan bahwa kedua peubah (Xdan Y) memiliki kecenderungan yang berlawanan (yaitu kenaikan nilai $X$, diikuti dengan penurunan nilai $Y$, demikian juga sebaliknya penurunan nilai $\mathrm{X}$ diikuti dengan kenaikan nilai $\mathrm{Y}$ ). Nilai $\mathrm{r}=-1$ menunjukkan kedua peubah berkorelasi negatif secara sempurna. Sebaran data tepat membentuk garis lurus

\section{PEMBAHASAN}

\section{Uji Normalitas}

Uji normalitas digunakan untuk
mengetahui apakah populasi data berdistribusi normal atau tidak (Prayitno: 2012). Jika didapatkan data berdistribusi normal, maka digunakan analisa parametrik, namun jika data tidak bertribusi normal digunakan uji non parametrik. Setelah dilakukan uji dari empat variabel menggunakan program SPSS, diperoleh hasil uji normalitas sebagai berikut:

Tabel 1. Uji Normalitas

\begin{tabular}{ccc}
\hline Variabel & \multicolumn{2}{c}{ Kolmogorov-Smirnov } \\
\cline { 2 - 3 } & Statistic & Sig. \\
\hline Program Pelatihan & 0,072 & 0,2 \\
Kompetensi & 0,155 & 0,0 \\
\hline
\end{tabular}

Dasar pengambilan keputusandata dinyatakan berdistribusi normal jika signifikansi lebih besar dari 5\% atau 0,05. Dari tabel diatas kita lihat pada kolom Kolmogorov-Smirnov dan dapat diketahui bahwanilai signifikansi variabel Program Pelatihan sebesar 0,200 dan besar dari 0,05. Artinya distribusi data variabel Program Pelatihan normal. Pada variabel kompetensi nilai signifikansi sebesar 0,000 dan kecil dari 0,05. Artinya distribusi data variabel kompetensi tidak terdistribusi normal. Oleh sebab itu metode statistik yang akan digunakan ialah statistik non parametrik.

\section{Uji Korelasi}

Setelah melihat gambaran secara objektif dari responden penelitian, selanjutnya akan dijelaskan analisis data yang diperoleh berdasarkan tanggapan responden yang berkaitan dengan variabel penelitian. Berdasarkan analisis data dengan menggunakan program SPSS, maka diperoleh hasil korelasi sebagai berikut: 
Tabel 2. Uji Korelasi Program Pelatihan-

\section{Kompetensi}

\section{Variabel}

Program Pelatihan

Kompetensi
Coefficient

1

0,253
Sig.

0,013
(Sumber : Output SPSS)

Hipotesis yang akan diuji adalah:

$H_{a} . \quad \begin{gathered}\text { Program pelatihan berkorelasi } \\ \text { signifikan terhadap peningkatan } \\ \text { kompetensi }\end{gathered}$

Dasar Pengambilan keputusan adalah dengan membandingkan nilai Sig.(2-tailed) dengan ketentuan jika nilai Sig.(2-tailed) besar dari 0,05 maka $\mathrm{Ha}$ ditolak atau jika nilai Sig.(2-tailed) kecil dari 0,05 maka Ha diterima

Dari hasil pengujian diperoleh nilai probabilitas variabel Program pelatihan dengan variabel Kompetensi sebesar 0,013. Nilai korelasi tersebut kecil dari 5\% atau 0,05, maka Ha diterima.Dengan demikian disimpulkan bahwa Program Pelatihan berkorelasi signifikan terhadap peningkatan Kompetensi.

\section{PENUTUP}

\section{Kesimpulan}

Berdasarkan hasil analisa yang telah diuraikan sebelumnya dapat ditarik kesimpulan yaitu Program pelatihan berkorelasi dengan peningkatan kompetensi. Hal ini ditunjukkan dengan hasil uji korelasi non parametrik dimana nilai probabiliti sebesar 0,013 (Spearman's rho) atau 0,011 (Kendall's tau_b).

\section{Implikasi}

96

Proses pengembangan sumber daya manusia melalui program pelatihan perlu dilakukan agar mutu pelayanan dapat ditingkatkan. Program pelatihan yang dilakukan akan sukses jika proses atau tahap-tahap dalam kegiatan tersebut dilaksanakan dengan tepat yang pada akhirnya akan memberikan hasil optimal melalui peningkatan kinerja, keterampilan dan kemampuan pegawai.

\section{Saran}

Adapun saran yang mungkin dapat peneliti berikan terkait dengan tema penelitian ini sebagai berikut:

a) Dibutuhkan suatu sistem perencanaan kebutuhan diklat (training need assesment), sehingga diklat yang dilaksanakan dapat menyentuh kebutuhan riil individu peserta dan juga kebutuhan organisasi peserta diklat.

b) Dilihat dari aspek efisiensi, anggaran penyelenggraaan diklat yang ada saat ini kurang memperhatikan efisiensi anggaran, karena jumlah anggaran yang dikeluarkan melebihi output yang dihasilkan. Sedangkan disisi lain masih banyak kebutuhan diklat teknis bagi PNS untuk meningkatkan kompetensi mereka dalam menjalanankan tugas. 


\section{DAFTAR PUSTAKA}

$\underline{10.22202 / \text { economica.2014.v3.i1.232 }}$

Ahdiyana, Marita, (2011) "Memperkuat Manajemen Strategis Dengan

Pengukuran Kinerja Dalam Organisasi

Sektor Publik", Universitas Negeri

Yogyakarta.

Asropi, (2005) "Analisis Keterkaitan Materi Diklatpim Tingkat II Dengan Model Kompetensi Kepemimpinan Pejabat Eselon II Pemerintah Daerah", Widyariset LAN-RI.

Axley, Lawrette, (2008) "Competenecy: A Concept Analysis", Nursing Forum, ProQuest.

Campion, Michael A, et al, (2011) "Doing Competencies Well: Best Practices In Competency Modeling", Wiley Periodicals, Inc.

Danim, Sudarwan, (2008) "Kinerja Staf dan Organisasi”, Pustaka Setia.
Dahiya, Sunita \& Jha, Ajeya, (2011) "Review Of Training Evaluation", International Journal of Computer Science and Communication, Vol. 2.

Dessler, Gary, (2006) "Manajemen Sumber Daya Manusia", PT INDEKS.

Hooper, Nick and Holmes, Gary, (2000) "Core Competence And Education", Kluwer Academic Publishers.

Lukito, Hendra, (2004) "Analisis Efektifitas Program Pengembangan Karyawan Melalui Pendidikan Dan Pelatihan di RS. DR. M. Djamil Padang”, Magister Manajemen Universitas Andalas.

Patching, Keith, (2011) "Throw Away That Leadership Competency Model", vol. 43 no. 3 2011, pp. 160-165, q Emerald Group Publishing Limited, ISSN 0019-7858.

Sekaran, Uma, (2006) "Research Methods For Business: Metode Penelitian Untuk Bisnis", Salemba Empat ; WILEY 